高カルシウム血症を伴った甲状腺癌症例の臨床的検討

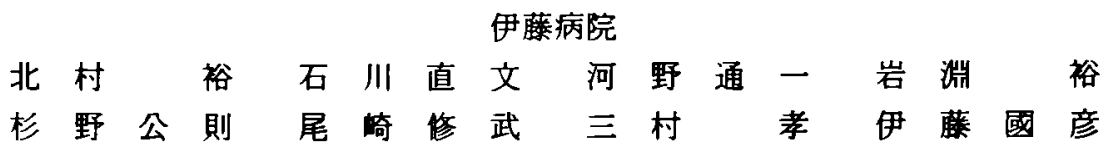

悪性重場に伴 5高カルシウム血症 (高 Ca 血症) は malignancy associated hypercalcemia (MAH) として知られている。甲状腺癌に括ける $\mathrm{MAH}$ の頻度, 病態について死 亡症例127例(未分化虞71例，乳頭癌44例，滤胞癌12例)について區床的に検討した. 11.0 $\mathrm{mg} / \mathrm{dl}$ 以上の高 $\mathrm{Ca}$ 血症は全症例中 8 例 $(6.3 \%)$ ，未分化癌では 5 例 $(7.0 \%)$ に認め られた. MAHの病態は, humoral hypercalcemia of malignancy (HHM) と local osteolytic hypercalcemia (LOH) に大別されるが，甲状腺癌のMAH8症例のうち，骨 転移を認めない 3 例と骨転移が軽度な 3 例は HHM の病態が考えられ，1例では血中 parathyroid hormone-related protein (PTHrP) が高值 $(11.1 \mathrm{pmol} / l(<2))$ である ことを確認した。著明な骨転移を認めた 2 例では，LOHの関与す考えられた。また未分 化癌の $4.2 \%$ 高 $\mathrm{Ca}$ 血症と白血球增多症が合併し，复数の液性因子の産生が示唆され た.

索引用語：甲状腺癌, 高カルシウム血症, parathyroid hormone-related protein (PTHrP), 白血球增多症

\section{锗 砉}

悪性董瘍に伴5高カルシウム血症（高 Ca 血症）は malignancy associated hypercalcemia (MAH) とし て知られ，各種悪性腫場で報告されている.MAH は高 Ca 血症の発現機序から humoral hypercalcemia of malignancy (HHM) \& local osteolytic hypercalcemia (LOH) に大別されている. HHM の発症因子 $と し て$ parathyroid hormone-related protein (PTHrP) が, LOHでは骨転移局所における種々の osteoclast activating factor (OAF) が認識されてい る.

甲状腺癌については，甲状腺原発局平上皮癌に高 $\mathrm{Ca}$

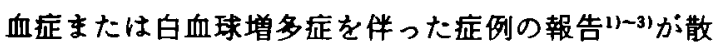
見され，白血球増多症にはgranulocyte-colony stimulating factor (G-CSF) の関与地)が証明されている. しかし高 Ca 血症については，培善癌練胞か.5の OAF 産生が報告"1されているるのの，甲状腺癌に伴ら高 $\mathrm{Ca}$ 血症の臨床的な報告はみられない.MAH は進行癌 にみられ，ときに直接死因にあなり得ることから甲状

1993年 2 月 15 日受付 1993年 5 月 12 日採用
腺癌死亡症例を対象にして，高 $\mathrm{Ca}$ 血症の颊度とその 病態について臨床的に検討を加えた。また甲状腺癌に おける白血球増多症の合併頛度についてあ検討した。

\section{対象と方法}

対象は1978年から1992年3月までの期間に当院で死 亡した甲状腺癌症例127例(未分化癌71例, 乳頭癌44例， 㯖胞癌12例)とした。平均年龄は67.3歳，男女比は 1 ： 2.8 , 剖検率は $29.1 \%$ あった。組織型は死亡時のるの とし，剖検，または手術標本組織所見により診断され た。释過中に血清 $\mathrm{Ca}$ 值が $11.0 \mathrm{mg} / \mathrm{dl}$ 以上を呈した症 例をとりあげ，臨床経過，検査所見，骨転移などにつ いて検討を加えた．骨転移は剖検, シンチグラフィー, CT, X 線写真により検索された。白血球増多症の診断 は末梢血白血球数 $30,000 / \mathrm{mm}^{3}$ 以上を示した重篤な感 染症を伴わない症例とした。

高 Ca 血症を合併した 1 例において血中 PTHrPを PTHrP ( $1-40)$ に対する polyclonal 抗体を用いた RIA キット（INCSTAR 社）で湘定()した。

\section{成 績}

1）高 Ca 血症の頻度（表 1)

甲状腺癌127例中 9 例に高 Ca 血症が合併したが，1 
表 1 甲状腺異"に伴う高カルシウム血症"* の頻度

\begin{tabular}{|c|c|c|}
\hline & 症例数 & 高 Ca 血应例（\%） \\
\hline 甲状腺疾 & 127 & $8(6.3)$ \\
\hline 未分化癌 & 71 & $5(7.0)$ \\
\hline 秏頭密 & 44 & $2(4.5)$ \\
\hline 浩胞癌 & 12 & $1(8.3)$ \\
\hline
\end{tabular}

表 2 甲状腺密・における骨転移の頪度

\begin{tabular}{|c|c|c|}
\hline & \multirow{2}{*}{ 骨転移（\%） } & 高 Ca 血症例 \\
\hline & & 骨転移（％) \\
\hline 甲状腺癌 & $27 / 127(21.3)$ & $5 / 8(62.5)$ \\
\hline 未分化㽾 & $12 / 71(16.9)$ & $3 / 5(60.0)$ \\
\hline 乳頭 癌 & $10 / 44(22.7)$ & $1 / 2(50.0)$ \\
\hline 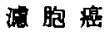 & $5 / 12(41.7)$ & $1 / 1(100.0)$ \\
\hline
\end{tabular}

*1978 92年, 伊藤病院の死亡症例

例は parathyroid hormone (PTH) が高値を呈し原発 性上皮小体機能六進症と診断されたため検討から除外 した。したかっって MAHは全症例で 8 例 (6.3\%)に合 併したか，組織別には未分化癌 5 例 $(7.0 \%)$ ，乳頭癌 2 例 (4.5\%)，清胞癌 1 例（8.3\%）であった。

2）骨転移の頻度（表 2)

骨転移の頻度は127例中27例（21.3\%）であり，組織 別では未分化癌12例 (16.9\%), 乳頭癌10例 (22.7\%), 濾胞癌 5 例 $(41.7 \%)$ と濾胞癌に高率に認められた。 高 $\mathrm{Ca}$ 血应を合併した 8 症例では 5 例 (62.5\%) と高頻 度に骨転移を認めたが，著明な多発性骨転移は 2 例の みで， 3 例は 2 箇所以下の小骨転移巣であった。

3）高 $\mathrm{Ca}$ 血症合併症例の点床経週（表 3）

高 Ca 血症の出現時期は死亡前 4 日から 6 力月で あったが，死亡前 3 週以内の発現が 5 例 (62.5\%) で あった，治療法としては補液と利尿薬およびカルシト ニンなどが使用されたが，高 Ca 血症は全例で死亡時 まで持続した，死因は症例 5 で高 Ca 血症が関与した 腎不全，症例 7 て腹腔内転移による腸閉塞，症例 8 で 著明な肺転移による呼吸不全のはかは，全身衰弱によ ろ癌死と考えられた。

\section{4）高 $\mathrm{Ca}$ 血症合併症例の検查所見（表 3)}

血清 $\mathrm{Ca}$ 值は経過中の最高値を示したか，最高17.2 $\mathrm{mg} / \mathrm{dl}$ まで上昇した症例がみられた。血清リン (IP) 値は，全体に低い傾向であった。高 $\mathrm{Ca}$ 血症出現時の堅

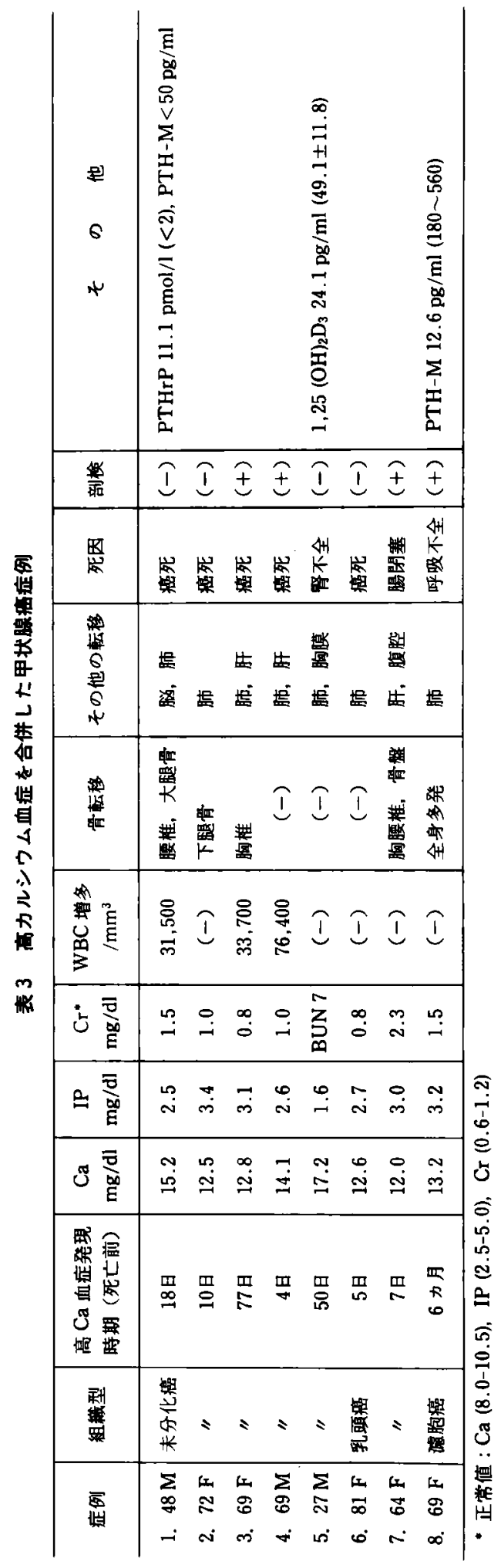




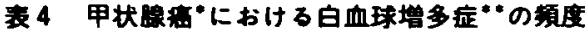

\begin{tabular}{|c|c|c|c|}
\hline & \multirow{2}{*}{ 㱏例数 } & \multicolumn{2}{|c|}{ 白血球增多应例 } \\
\hline & & 店列数 $(\%)$ & 高 $\mathrm{Ca}$ 血应合併例（\%） \\
\hline 甲状腺息 & 127 & $22(17.3)$ & $3(2.4)$ \\
\hline 分分化舟 & 71 & $17(23.9)$ & $3(4.2)$ \\
\hline 乳頭悹 & 44 & $5: 11.4)$ & 0 \\
\hline 葸胞舟 & 12 & $0(0.0)$ & 0 \\
\hline
\end{tabular}

- 1978 92年, 藤病完の死亡店例

“一束梢血 $\mathrm{WBC} 30.000 / \mathrm{mm}^{3}$ 以上

機能については，症例 7で血清クレフチニン $(\mathrm{Cr}) 2.3$ $\mathrm{mg} / \mathrm{dl}$ と腎機能障害を示し, 症例 1 と 8 で血清 Cr 1.5 $\mathrm{mg} / \mathrm{dl}$ と軽度の腎機能低下を翟めたはかは正常筑囲 であった．血中 PTHrPを测定し得た症例 1 では， PTHrP 11.1pmol $/ l(<2)$ と高値を示し, 血清 PTH-M は<50pg/ml(180 560) と低値であった，症例 5 では 血中 $1,25(\mathrm{OH})_{2} \mathrm{D}_{3} \not 324.1 \mathrm{pg} / \mathrm{ml}(37 \sim 61)$ と低值を, 症 例 8 でも血清 PTH-M が $12.6 \mathrm{pg} / \mathrm{ml}$ と低值をとった。 督原性 cyclic AMP 則定はいずれの症例においても施 行されなかった。

\section{5）白血球增多症の類度（表 4)}

甲状腺癌127例中22例 (17.3\%) に白血球增多症を認 めた。組樴型別では未分化癌で17例（23.9\%）と高い 頻度で白血球增多症がみられ，この5ち 3 例は高 $\mathrm{Ca}$ 血症も伴っていた（表了）.

\section{考察}

MAH の頻度は adult T cell leukemia $て ゙ 80 \%{ }^{61}$, 多 発性骨葡畽で30 - 60\%, 進行固形癌では各種扁平上皮 癌で $25 \sim 50 \%$, 乳癌で $20 \%$, 胃癌・腎癌で $10 \%$ の頻度” などと報告されている。死亡した著明な甲状腺進行虎 においては6.3\%の願度でMAHがみられたか，他の 悪性娾瘍と比較して低いものであった，末分化癌症例 はすべて死亡しているので, 今回の調査による7.0\%が 末分化惩における MAH の頻度と考えられた．分化癌 症例の 3 例中 2 例に剖検が施行されており，分化癌に

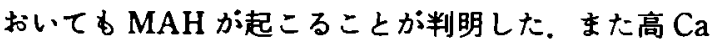
血症の発見時期は死亡前 1 週以内が 3 例にみら九，最 長です死亡前 6 カ月で，高 $\mathrm{Ca}$ 血症の出現は予後不良 因子の一つとも考えられた。

MAH はHHM とLOHに分けられるが，HHM は 畽膓に上り産生される夜性因子が全身的に作用し，特 に破骨紐胞による骨吸収を促進して高 Ca 血症を起こ 寸病態でほほとんどの应例ではPTHrPが発症因子と されている.PTHrPは1987年に単離同定891され，遺层
子構造 ${ }^{10)}$ 。决定された分子量約16,000の蛋白で141の フミノ酸より成り， $\mathrm{N}$ 末端 1 34の部位が PTH と類 似し，PTH受容体を介して作用する゙1121. しかし PTHrPによる HHM では, 血清 Ca の上㫒, 血清P の 低下，羿原性 cyclic AMP の增加に成しては原発性上 皮小体機能六進症と同様であるが, PTH と血清1, $25(\mathrm{OH})_{2} \mathrm{D}_{3}$ の低值および低 $\mathrm{Cl}$ 性 alkalosis を示す点 で異なっている ${ }^{13)}$ 。さ最近 PTHrP は畽場組载のみ でなく，正常組織にす広く存在し，細胞の成長や分化 に関与"1)していることも知られている。

PTHrP の測定は生物活性を持つ $\mathrm{N}$ 末端による測 定 ${ }^{5115)}$ と比較的安定で血液以外にも尿中の湘定す可能 な C 末端(3)16)によるすのが報告されている。症例 1 に 用いたPTHrP $(1 ４ 0) \mathrm{N}$ 末端抗体による測定法での 正常值は検出限界の $2 \mathrm{pmol} / l$ 以下であるか，この測定 法によると骨転移のないMAH の症例では $100 \%$ に, MAH を伴った骨転移のある固形癌症例之乳癌症例で るそれぞれ64\%，65\%に PTHrP が検出されている5゙.

多発性骨䯣腫と乳癌骨転移に代表される LOH で は，骨浸洞部において interleukin-1, tumor necrosis factor, interleukin-6などの OAF の関与により破骨細 胞を誘導活性化して骨吸収を促進することで高 Ca 血 症を引き起こすと考えられている17．多発性骨骾畽に おける MAH のほぼ全例が LOH といわれるが, 高 Ca 血症の発症には骨病変だけでなく， light chainによる 堅障害が重要な因子であり，骨吸収によるCaが堅排 泄量を䍟駕することで LOH が生じる7.しかし正常な 堅監は 1 日 $1 \mathrm{~g}$ 以上の Ca の排泄が可能18)であるため, 一般には骨転移に上る骨吸収のみでは高 Ca 血店の発 生は困難であり，PTHrPによる腎での Ca 再吸収促進 が加わることで高 Ca 血症が生しる。乳癌骨転移症例 の高 Ca 血症でさえ約 $50 \%$ はHM ${ }^{7}$ とされるが，実際 には骨転移の有無に関わらずMA では約 $80 \%$ 以上 が HHM の病態19)といわれている.

MAH を合併した甲状腺癌各症例の病態について検 討してみると，症例 4，5，6は骨転移か存在しない ことから HHMであり, 症例 5 で認めた血清1, $25(\mathrm{OH})_{2} \mathrm{D}_{3}$ の低值 $\mathrm{HHM}$ を示唆している. 症例 1 ,

2、3は少数の骨転移巣が存在したが, 症例 1 では血 中PTHrPの高値が確認されたことから HHM の病 態であり，他の 2 症例も高 $\mathrm{Ca}$ 血症発現時の腎機能は 正常であったことから HHM が強く示㖫された。症例 7 では多発性骨転移と腸閉塞による腎機能障害の出現 に伴って発症した高 Ca 血症であることから，また症 
例 8 では軽度の腎機能障害之全身の著明な骨転移の存 在から、LOH の関与も考えられた。臨床的な検討では あるが, 甲状腺癌における MAHにおいてすHHM の 病態が多いと推測された，今後はPTHrPを娜定する ことで, PTHrP 值により高 Ca 血症の病態をより正確 に把握できるすのと思われた。

甲状腺癌死亡症例における白血球増多症の頻度は 17.3\%であったが，未分化癌では23.9\%の高い頻度で 白血球增多症を合併した.さらに未分化癌の $4.2 \%$ に白 血球増多症と高 $\mathrm{Ca}$ 血症を同時に合併したが，このな かに血中 PTHrP の高値症例が含まれた，白血球増多 症と高 Ca 血症を伴った甲状腺癌から樹立された細胞 株で G-CSF と数種の cytokine 産生が報告"dされて おりこれらの臨床例ですPTHrPゃG-CSFなどの 液性因子の産生が示唆された。

\section{結語}

甲状腺進行癌に伴 5高 $\mathrm{Ca}$ 血症の頻度は6.3\%で，こ の5ち末分化癌であ7.0\%であったことから，甲状腺癌 における MAHの合併頻度は低いすのであった。 $\mathrm{MAH}$ の病態については, 他の悪性腫瘍と同様に, LOH 上りむHHM が多いと考えられた：未分化癌の 1 例で血中 PTHrP の高値が確認された．高 Ca 血症 と白血球増多症を同時に示した症例が未分化癌の $4.2 \%$ に存在した。

\section{文献}

1) Sato K, Fujii Y, Ono M, et al : Production of interleukin 1-like factor and colony-stimulating factor by a squamous cell carcinoma of the thyroid (T3M-5) derived from a patient with hypercalcemia and leukocytosis. Cancer Res 47 : 6474-6480, 1987

2) Saito K, Kuratomi $Y$, Yamamoto K, et al : Primary squamous carcinoma of the thyroid associated with marked leukocytosis and hypercalcemia. Cancer 48: 2080-2083, 1981

3) Okabe T, Nomura H, Ohsawa N: Establish. ment and characterization of a human colony stimulating factor producing cell line from a squamous cell carcinoma of the thyroid. J Natl Cancer Inst 69 : 1235-1243, 1982

4) Tohyama K, Yoshida $Y$, Ohashi K, et al : Production of multiple growth factors by a newly established human thyroid carcinoma cell line. Jpn J Cancer Res 83 : 153-158, 1992

5) Grill V, Ho P, Body JJ, et al: Parathyroid hormone-related protein: Elevated levels in both humoral hypercalcemia of malignancy and hypercalcemia complicating metastatic breast cancer. J Clin Endocrinol Metab 73 : 1309-1315, 1991

6）松本俊夫：成人 $\mathrm{T}$ 細胞白血病に括ける副甲状腺 ホルモン闲蛋白 (PTHrP) の発現と高カルシウ 厶血症の出現。日内分泌会誌 $66 ： 1255-1259$ ， 1990

7) Ralston SH: The pathogenesis of humoral hypercalcemia of malignancy. Bone Mineral Res $7: 139-173,1990$

8) Buris $W J, W u T$, Bunch $C$, et al : Identification of a novel 17,000-dalton parathyroid hormone-like adenylate cyclase-stimulating protein from a tumor associated with humoral hypercalcemia of malignancy. J Biol Chem 262 : 7151-7156, 1987

9) Moseley JM, Kubota M, Diefenbach-Jagger H, et al: Parathyroid hormone-related protein purified from a human lung cancer cell line. Proc Natl Acad Sci USA 84 : 5048-5052, 1987

10) Suva LJ, Winslow GA, Wettenhall REH, et al : A parathyroid-related protein implicated in malignant hypercalcemia : Cloning and expression. Science $237: 893-896,1987$

11) Mangin $M$, Webb $A C$, Dreyer $B E$, et al : Identification of a cDNA encoding a parathyroid hormone-like peptide from a human tumor associated with humoral hypercalcemia of malignancy. Proc Natl Acad Sci USA 85: 597 $-601,1988$

12) Orloff JJ, Wu TL, Stewart AF : Parathyroid hormone-like proteins: Biochemical responses and receptor interactions. Endocr Rev 10:476 $-495,1989$

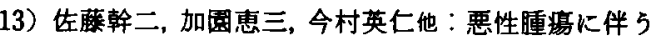
高カルシウム血症。ホルモンと臨 $40: 609-615$, 1992

14) Kramer S, Reynolds FH, Castillo M, et al : Immunological identification and distribution of parathyroid hormone-like protein polypeptides in normal and malignant tissues. Endoclinol $128: 1927-1937,1991$

15）和田知益，大谷英樹：悪性尰瘍に伴5高カルシゥ ム血症を㤫起する副甲状腺ホルモン関連蛋白 
(parathyroid hormone related protein; PTHrP)－新しいホルモン性值燩マーカーとして のPTHrPの検討一。臨床病理 38：288-293, 1990

16）福永代夫，三宅真理子，松田信義：C-PTHrP RIA キットRよる血中および尿中C 末端副甲状腺ホル モン関連ベブチド浱度の測定. ホルモンと臨 39 ： 761-765, 1991

17）岡野一年：カルシウム・骨代謝とサイトカイン. ホ
ルモンと臨 $40: 129-135,1992$

18）永田直一：要性重場と高カルシゥム血症一 $\mathrm{LOH}$ -. Clinical Calcium 2: 660-667, 1992

19) Stewart AF, Horst R, Deftos LJ, et al: Biochemical evaluation of patients with cancerassociated hypercalcemia. Evidence for humoral and nonhumoral groups. N Engl J Med 303 : 1377-1381, 1980

\section{CLINICAL STUDY OF THYROID CANCER WITH HYPERCALCEMIA}

\section{Yutaka KITAMURA, Naofumi ISHIKAWA, Michikazu KOHNO, Hiroshi IWABUCHI, Kiminori SUGINO, Osamu OZAKI, Takashi MIMURA and Kunihiko ITO Ito Hospital}

Hypercalcemia in the patients with malignant tumor has been known as malignancy associated hypercalcemia (MAH). Incidence and pathogenesis of MAH in thyroid cancer was clinically studied in 127 patients who died of thyroid cancer, including 71 patients with anaplastic carcinoma, 44 with papillary carcinoma and 12 with follicular carcinoma. Hypercalcemia with more than $11.0 \mathrm{mg} / \mathrm{dl}$ of serum calcium was found in $8(6.3 \%)$ out of the total 127 cases or $5(7.0 \%)$ out of 71 cases of anaplastic carcinoma.

On the basis of the mechanisms, MAH was divided into humoral hypercalcemia of malignancy (HHA) and local osteolytic hypercalcemia (LOH). Of the 8 cases of thyroid cancer with $\mathrm{MAH}, 3$ cases without bone metastasis and 3 cases with few bone metastasis, including one case demonstrated an elevation $(11.0 \mathrm{pmol} / \mathrm{l}(<2))$ in parathyroid hormone-related protein (PTHrP), were considered to be accompanied with HHM. The other 2 cases with remarkable bone metastasis might be associated with LOH.

A fact that the association of hypercalcemia as well as leukocytosis was found in $4.2 \%$ of all anaplastic carcinomas may suggest that the tumors in these cases might produce several humoral factors. 